\title{
Landscape modeling of the potential natural vegetation of Santa Catalina Island, California
}

\author{
Travis Longcore ${ }^{1}{ }^{*}$, Nina Noujdina ${ }^{1}$, and Peter J. DiXon ${ }^{2}$ \\ ${ }^{1}$ University of Southern California, Los Angeles, CA \\ ${ }^{2}$ Catalina Island Conservancy, 330 Golden Shore, \#170, Long Beach, CA 90802
}

\begin{abstract}
The vegetation of Santa Catalina Island has been significantly transformed through a history of introduction of exotic plant species and disturbance by large introduced herbivores. Many of these disturbances have been reduced in recent decades, using measures such as carefully controlling the number of bison and removing cattle, sheep, feral pigs, and goats. The success of subsequent vegetation restoration actions depends on the choice of the right plant community for a location, which may not be obvious for an island with extensive areas dominated by exotic species. Environmental niche modeling is an approach to re-create the spatial distribution of habitat types for such a purpose. Such models, however, often require both presence and absence data to be meaningful, while in this scenario absence is misleading because it may reflect a long history of disturbance. Maximum entropy modeling is a technique to model species distributions with presence-only data that has been shown to produce accurate results. We used this modeling tool to model the environmental niche for distinct vegetation types, conceptualized as potential natural vegetation, on Catalina Island as a means to predict locations where restoration actions would be most successful and to predict potential natural vegetation prior to anthropogenic disturbance. Using an existing vegetation map, we extracted random points from within the polygons defining each native vegetation type. We then modeled the habitat suitability for each habitat using high-resolution environmental data that included elevation, aspect, hillshade, northeastness, slope, solar radiation, and topographic wetness index. The resulting models were combined to produce a map of potential natural vegetation. A 1977 map of potential natural vegetation included 4 vegetation types (woodland, chaparral, scrub, and grassland) to which we compared our results. Our new model of potential natural vegetation has high spatial complexity and high resolution. It also shows naturalistic responses to topography that are consistent with the broad patterns mapped in 1977 while providing fine-scale resolution to inform restoration efforts.
\end{abstract}

Resumen.-La vegetación de la isla Santa Catalina se transformó de manera significativa debido al historial de especies de plantas exóticas introducidas y a la perturbación generada por la introducción de grandes herbívoros. Gran parte de esta perturbación disminuyó en las últimas décadas, tales como el control cuidadoso del número de bisontes, la eliminación del ganado vacuno, las ovejas, los jabalíes y las cabras. El éxito de futuras medidas de restauración de la vegetación dependerá de la correcta elección de la comunidad vegetal para la localidad, lo que puede no ser evidente en una isla con grandes áreas dominadas por especies exóticas. El modelado de nichos ambientales es un enfoque que recrea la distribución espacial de los tipos de hábitats. Sin embargo, estos modelos a menudo requieren que los datos de presencia y de ausencia sean significativos, mientras que en este escenario la ausencia es confusa, ya que puede reflejar el largo historial de perturbación. El modelado de máxima entropía es una técnica que recrea la distribución de las especies únicamente con datos de presencia que demuestren resultados precisos. Utilizamos esta herramienta de modelación para recrear el nicho ambiental de los distintos tipos de vegetación de la isla Santa Catalina (conceptualizadas como vegetación natural potencial) como un medio para predecir los lugares donde las medidas de restauración serían más exitosas y para predecir la vegetación natural potencial antes de la perturbación antropogénica. Usando un mapa de vegetación vigente, seleccionamos aleatoriamente, puntos dentro de los polígonos que definen cada tipo de vegetación nativa. Luego modelamos el hábitat adecuado para cada hábitat, mediante datos ambientales de alta resolución que incluyen elevación, aspecto, sombreado, disposición orientada al noreste, pendiente, radiación solar e índice de humedad topográfica. Los modelos resultantes se combinaron para crear un mapa de vegetación potencial natural. Comparamos nuestros resultados con un mapa de vegetación potencial natural de 1977 que incluía cuatro tipos de vegetación (bosques, chaparrales, matorrales y pastizales). Nuestro nuevo modelo de vegetación potencial natural presenta alta complejidad espacial, alta resolución y muestra respuestas naturalistas a la topografía, todo esto es consistente con los amplios patrones mapeados en 1977, al mismo tiempo que proporcionan una propuesta detallada para informar las medidas de restauración.

*Corresponding author: longcore@usc.edu 
The natural vegetation of the California Channel Islands is of significant interest to ecologists and island managers in light of the severe disturbance and degradation caused by histories of agriculture and ranching on this biodiverse archipelago. Interpretation of the effects of current and prehistoric human activities depends on a view of what vegetation might be supported by the biophysical patterns and processes present at a given point in time (Rick et al. 2014). Similarly, the goals of current management strategies depend on a realistic understanding of which vegetation types might be supported by the geophysical patterns of the island landscapes. Now that significant progress has been made toward removal or management of exotic mammals (Keitt et al. 2002, Donlan et al. 2003, Nogales et al. 2004, Kindsvater 2010), natural resource managers on the islands are focusing even more on which vegetation types to restore, and where.

The concept of potential natural vegetation (PNV) offers an avenue to evaluate landscapes that have been impacted by humans relative to both their past condition and possible futures. The PNV concept was introduced by Faber (1937) and elaborated and promoted by Tüxen (1956). It offers a framework to describe what vegetation might exist in the absence of human disturbance, being defined as "the vegetation that would develop in a particular ecological zone or environment, assuming the conditions of flora and fauna to be natural, if the action of man on the vegetation mantle stopped and in the absence of substantial alteration in present climatic conditions" (Tüxen 1956, translated in Gallizia Vuerich et al. 2001). The concept has been the subject of debate and redefinition over time (Gallizia Vuerich et al. 2001) to determine whether the PNV is that which would occur should human disturbance cease (Westoff and van der Maarel 1978), or whether it is the final stage of succession (Moravec 1969, Härdtle 1995) synonymous with the Clementsian concept of "climax" (Küchler and Zonneveld 1988). Current understanding suggests incorporation of irreversible alterations in environmental conditions (that is, a focus on potential rather than reconstructed vegetation) (Härdtle 1995) and inclusion of more edaphic and topographic variables than those included in the original focus on climate in creating PNV maps (Gallizia Vuerich et al. 2001). Recent criticisms of the PNV concept focus on the difficulties with conceiving of vegetation types as coherent entities in light of the known individualistic character of species movements over ecological time (Carrión and Fernández 2009). The concept retains its utility in environmental planning for the assessment of vegetation (Fischer et al. 2013) and in investigating the potential impacts of changed environments, such as those from changed climates (del Río and Penas 2006, Bryn 2008, Lapola et al. 2008), or the removal of stressors such as exotic herbivores.

The PNV concept may be a "provisionally useful fiction" (Jackson 2013), in that the real world never matches the ideal, because climatic variation, disturbance patterns, and accidents of history affect the particular pattern of actual vegetation at any particular point in time. Yet it offers the ability to fill in gaps in historical knowledge and to generate hypotheses for management actions. For example, conservation goals may not be consistent with the capacity of the landscape to support them because of misunderstandings of historical distributions (Szabó et al. 2017). Two major critiques of PNV as historically practiced remain. First, PNV maps were often created with expert knowledge (Fischer et al. 2013) and therefore subject to biases and lacking in granularity. Second, PNV was mapped at the regional level (Tüxen 1956), and resulting maps tended not to have sufficient spatial resolution for site-level analysis (Zerbe 1998).

Spatially explicit numerical modeling offers a remedy to the coarse resolution and biases of regional-scale PNV maps. Numerical modeling with GIS has become more common and has been used to model PNV, including in Germany (see Fischer et al. 2013), Switzerland (Brzeziecki et al. 1993), the Czech Republic (Tichý 1999), Norway (Hemsing and Bryn 2012) and China (Liu et al. 2009). With sufficient input data resolution, landscape modeling can offer a highly detailed assessment of potential environmental niches across the landscape; and indeed, this practice is commonplace for the production of individual species models. If a machine-learning approach is used, the biases associated with expert production of maps can be avoided.

Maxent is a predictive statistical GIS modeling method that uses machine learning 
based on a maximum entropy algorithm (Phillips et al. 2006, Phillips and Dudík 2008, Elith et al. 2011). The program processes environmental variables and evaluates the combinations and interactions between the variables to predict the probability of encountering the modeled species across the landscape, based on the similarity of the environmental conditions (Phillips et al. 2006, Raes and ter Steege 2007, Wollan et al. 2008, Newbold et al. 2009, Kruijer et al. 2010). Maxent has been used to assess past, potential, realized, and future species distributions (Tingley et al. 2014, Soto-Berelov et al. 2015, Bose et al. 2016, Taylor et al. 2016); model vegetation dynamics (Rodríguez-Sánchez and Arroyo 2008, Papeş et al. 2012, Soto-Berelov et al. 2015); assess shifts for a niche shared by species communities (Velásquez-Tibatá et al. 2013, Bertram and Dewar 2015, Nazeri et al. 2015); model niches for endangered species (Babar et al. 2012), prioritize areas for conservation (Gaucherel et al. 2016, Akhter et al. 2017); define niche constraints (Marino et al. 2011, Camps et al. 2016); and assess risk of invasive species (Bromberg et al. 2011, Duursma et al. 2013, Simpson and Prots 2013, McDowell et al. 2014, Tingley et al. 2014, Collette and Pither 2015, Choudhury et al. 2016).

The advantage of Maxent over other ecological models is that it requires presence data only and produces results of high accuracy (Elith et al. 2011, Collette and Pither 2015, Nazeri et al. 2015, Choudhury et al. 2016). In addition, Maxent evaluates each explanatory variable in its relative importance for the prediction and assigns a rank to it.

We therefore use Maxent as a model to develop a PNV map for Santa Catalina Island, a California Channel Island, following similar approaches used elsewhere (Hemsing and Bryn 2012, Zhang et al. 2013). Hemsing and Bryn (2012) compared 3 PNV models for a mountainous region in Norway, with one model created from expert opinion, one from a rulebased GIS model, and one from Maxent. They found desirable attributes of the Maxent approach, including its production of relative probability maps, its objective approach, and the ease of repeat model runs. Maxent or a rule-based approach was preferable to an expert map in all but the most disturbed localities (Hemsing and Bryn 2012). Similarly, Zhang et al. (2013) used Maxent to model distributions with functional groups of plant species as the unit of analysis.

A challenge to the use of Maxent for this purpose is the wide extent of exotic vegetation types on Catalina Island (Knapp 2005). European grasses predominate across many areas of the island, especially on disturbed soils and on shallow, rocky ridges and slopes (Thorne 1967). These grasses include species of the genera Bromus, Avena, and Hordeum, and some previous observations suggested that native grasses (Stipa pulchra, S. cernua, and S. lepida) returned to such locations when grazing pressure was removed (Thorne 1967). Exotic annual grasslands have replaced areas that may once have been occupied by chaparral or shrublands, or they may have replaced native grasslands in other locations, making the interpretation of their presence challenging.

Our goal was to develop a map of PNV for Santa Catalina Island as a means both to understand the historical distribution of vegetation types across the island and to provide testable hypotheses to guide ongoing plant restoration efforts. Suppression of woody plant regeneration through herbivory by introduced ungulates is a long-term concern of island managers (Minnich 1980, Stratton 2009, Knapp 2010a, 2010b, Ramirez et al. 2012), and a detailed and high-resolution understanding of the environmental niche occupied by woody vegetation types would be a key output of a PNV map. This effort builds on previous species modeling efforts (Franklin and Knapp 2010) and introduces higher-resolution environmental data and a vegetation community approach. We also compare the results to an existing low-resolution map of Catalina Island PNV, created as part of a statewide effort by Küchler (1977), which predicts that 4 vegetation types would have dominated the predisturbance landscape (coastal sage scrub, grassland, chaparral, and woodland).

\section{Methods \\ Study Area}

Santa Catalina Island is located $32 \mathrm{~km}$ off the shore of Los Angeles County, California, in the Pacific Ocean (Schoenherr et al. 1999) (Fig. 1). It is part of the California Channel Islands, which are all under varying degrees of conservation ownership and support many rare and endemic plant and animal species 


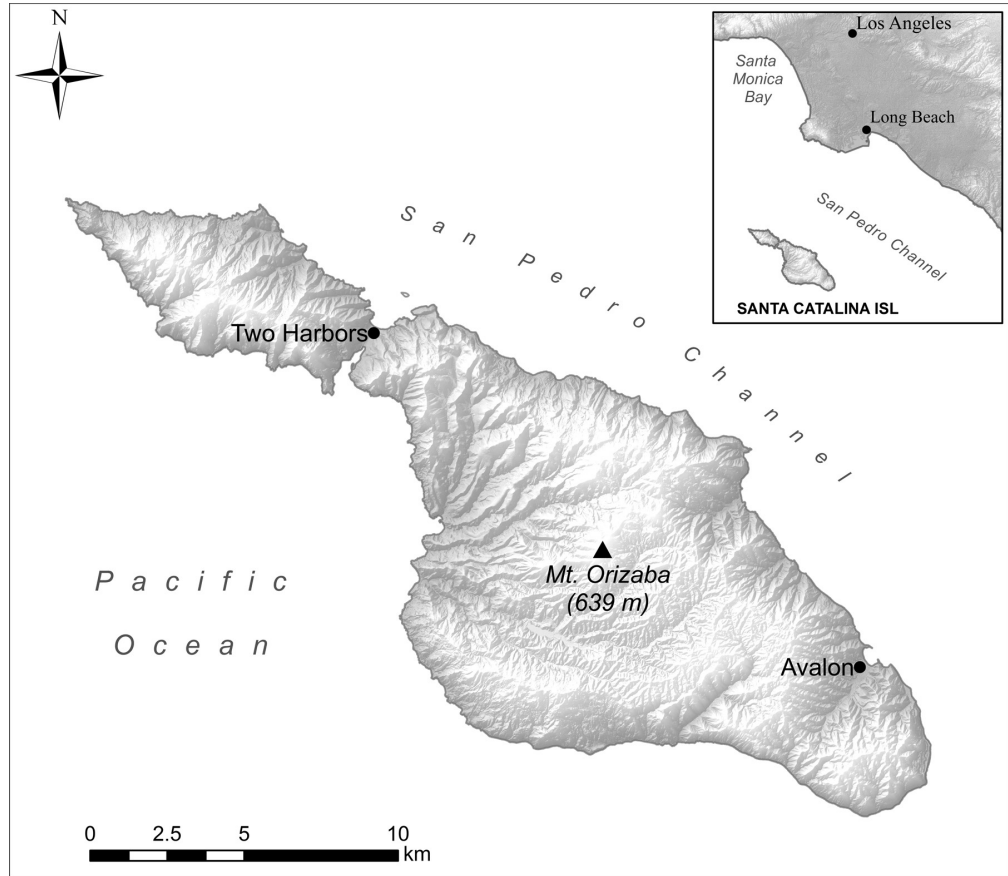

Fig. 1. Location and topography of Santa Catalina Island, Los Angeles County, California.

(Rick et al. 2014). The island is $194 \mathrm{~km}^{2}$ and ranges from sea level to $640 \mathrm{~m}$ elevation. It is a geologically young island, a little more than 100 million years old with 3 major geological formations: Catalina schist, Catalina pluton, and various andesite rocks (Rowland 1984). The climate is a marine-influenced Mediterranean-type climate with an average annual temperature of $15.8{ }^{\circ} \mathrm{C}$ and an average annual precipitation of $29.2 \mathrm{~cm}$ over the past 41 years (ncdc.noaa.gov).

\section{Environmental Niche Modeling}

We used Maxent to model PNV of Santa Catalina Island, California, in the absence of grazing disturbance. Following Moravec (1998), we relied on an actual vegetation map (Knapp 2005) to model potential vegetation and a high-resolution digital elevation model and its derivatives to serve as environmental layers (LAR-IAC 2006). Both data sets had been produced within a 1-year time period, which minimized the odds of change in vegetation communities.

VEGETATION MAP OF CATALina Island.-The actual vegetation map of Catalina Island was developed from aerial imagery obtained in
2000 and comprised 50 classes, each describing a specific land cover, vegetation type, or vegetation community (Knapp 2005). We chose this map as a baseline because of its exhaustive nature, fine spatial resolution of 4-ha mapping units, and homogeneity of polygons; each class represented a thoroughly described, uniform vegetation community characterized by 1 or 2 dominant species or land cover types.

Our main interest was to model potential vegetation cover of the island with native species. Thus, from the available 50 classes, we selected 11 classes that represented pure stands of native vegetation: Island Woodland (IW), Coastal Sage Scrub (CSS), Island Chaparral (IC), Coastal Bluff Scrub (CBS), Coastal Marsh (CM), Maritime Cactus Scrub (MCS), Mulefat Scrub (MFS), Riparian Herbaceous $(\mathrm{RH})$, Southern Beach and Dune (SBD), and Southern Riparian Woodland (SRW). We also included Grassland (GR) (even though current grassland areas are dominated by exotic species) as indicators of areas where native grasses and forbs might have been distributed as posited by Thorne (1967). The actual vegetation map was provided in a Esri shapefile format and was projected to UTM Zone 11 
with the NAD83 datum. It was reprojected to the California State Plane Coordinate System with NAD 1983 to match the projection of the environmental layers.

ENVIRONMENTAL VARIABLES.-A $1.5-\mathrm{m}$ resolution digital elevation model (LAR-IAC 2006) served as a source for other explanatory variables that are frequently used in environmental studies. We derived slope, hillshade, solar radiation index, aspect, northeast-southwest gradient, and topographic wetness index from the digital elevation model. Slope is a measure of the steepness of a surface, usually expressed in degrees or as a percentage. We converted its values to radians to fit Maxent input requirements. Hillshade simulates the shadow cast by the sun onto the terrain and thus emphasizes the 3-dimensional aspect of the area. Solar radiation index is a total amount of incoming solar energy calculated for each pixel. This variable depends on slope, aspect, and relative position of the sun. Aspect is another topographic element that describes the compass direction the slope is facing and is measured in degrees from north. Even though aspect is a circular variable, we included it in the input data set, relying on Maxent's ability to omit variables that have little or no effect on the model. Aspect, however, is commonly transformed by trigonometric functions, such as cosine and sine, thereby retaining the continuity of the variable (Roberts 1986, Palmer 1993). Northeast-southwest gradient is a generalized proxy for the "wetness" characteristic and fits the environment of the Channel Islands (Paudel et al. 2016). This variable was calculated in ArcGIS 10.3.1 (Esri, Redlands, CA) using Map Algebra expression

$$
\begin{gathered}
\text { Con }([\text { Aspect }]=-1,0, \operatorname{Sin}(([\text { Aspect }]+45) \\
* 3.14159 / 180)) .
\end{gathered}
$$

Topographic wetness index (TWI), a wetness proxy, is derived from slope, flow accumulation, and flow direction. It was calculated in ArcGIS using Map Algebra expression

$$
\begin{gathered}
\text { Ln(“Flow Accumulation"/ } \\
(\operatorname{Tan}(\text { "Slope-in-Radians")) + 0.01) . }
\end{gathered}
$$

The variables described above were selected from a larger set of environmental layers that included geology and soils. The resolution of the geology and soils layers was much coarser
TABLE 1. Training sample sizes for vegetation classes.

\begin{tabular}{lrr}
\hline Vegetation class & \multicolumn{1}{c}{$\begin{array}{c}\text { Area } \\
\left(\mathrm{m}^{2}\right)\end{array}$} & $\begin{array}{c}\text { Sample } \\
\text { size }\end{array}$ \\
\hline Coastal bluff scrub & 313,843 & 272 \\
Coastal marsh & 9639 & 50 \\
Coastal sage scrub & $3,9183,246$ & 2418 \\
Grassland & $2,3349,156$ & 1446 \\
Island chaparral & $3,7252,699$ & 2029 \\
Island woodland & 725,927 & 554 \\
Maritime cactus scrub & 11,512 & 50 \\
Mule fat scrub & 4836 & 10 \\
Riparian herbaceous & 98,116 & 199 \\
Southern beach and dune & 520,001 & 276 \\
Southern riparian woodland & 651,417 & 450 \\
\hline
\end{tabular}

than the rest of the data, which would have caused significant reduction of spatial resolution of the input data as a whole, adding vagueness to the final results. To improve the model in the future, we highly recommend adding these environmental variables at a resolution similar to the base data set. Before including the input layers, we tested them for multicollinearity using the Exploratory Regression tool in ArcMap to confirm that no layer had a variance inflation factor that exceeded 2.5 (corresponding to a correlation with other variables of 0.6). The tool was run on a subset of 5000 points randomly selected from each layer. All layers were converted to Esri ASCII grid format to meet Maxent input requirements.

Training SAmPLES.-Polygons of the actual vegetation map that corresponded to target vegetation classes were selected and buffered with a negative distance of $1 \mathrm{~m}$ to omit potential transitional zones between classes. Training points for each class were built in ArcGIS as random samples, stratified by corresponding polygon area, with a 3-m minimum allowed distance between points. A pool of random points for each vegetation class was then used as the Maxent input according to the area covered by the vegetation class (Table 1 ).

Model development.-We developed a model for each vegetation class with 40 replications using subsampling with 20 random test points withheld in each model run and a maximum model iteration of 5000. In subsampling replication, the presence points are repeatedly split into random training and testing subsets, in accordance with the set proportion. Spatial resolution of modelled species distribution corresponded to the resolution of input layers and was equal to $1.5 \times 1.5 \mathrm{~m}$. Model performance was assessed using the area under the 
receiver operating characteristic curve (AUC) statistic. The receiver operating characteristic (ROC) curve is a plot of the values of sensitivity against 1 - Specificity. In short, a model with good discriminating ability has high sensitivity and high specificity, and the line of such a curve tends to be closer to the upper left corner of the plot area; thus, the area under it will increase. Poor-fit models, on the other hand, will have ROC curves approximating a 45-degree diagonal line on the plot area. The model also produced jackknife tests for regularized training gain, test gain, and AUC for each vegetation class.

Each model was thresholded to identify whether a vegetation class could be expected at each pixel. We then overlaid the predicted distributions such that models that performed best by AUC were layered below models with lower performance so that the high-performing models would not swamp the lower-performing models. We adjusted this order by hand so that the highest values of each model were mapped in the composite. We also developed a composite map based on a strict rule-based approach, where the model suitability values were standardized to a scale of 0 to 1 , and each pixel was assigned the vegetation classification with the highest standardized value at that point (Supplementary Material 1).

\section{Comparison of Composite Model to 2005 and 1977 Maps}

Our composite model of vegetation differed from the actual vegetation map on which it was based in that we assigned each pixel to the class having the highest suitability value, even if that class was not the vegetation present at that location. We therefore compared our classifications with the 2005 actual vegetation map to see how it differed from our idealized environmental niche models for those locations. For comparison, we selected the 4 most dominant vegetation types: Coastal Sage Scrub, Island Woodland, Grassland, and Island Chaparral. The raw raster maps modeled by Maxent for each of the 4 vegetation classes represented a probability surface of that species being encountered in the area, other things being equal. We set a threshold of 0.51 for these layers to set a reasonable feasibility extent for each of them. We then applied a generalization technique to remove isolated pixels from the maps. After testing several smoothing methods, including filtering and focal statistics, we chose the expand-and-shrink method. A sequence of expanding by 2 followed by shrinking by 3 and finishing with expanding by 1 not only eliminated isolated single pixels, but also preserved the original clusters of pixels and thus resulted in a smooth map suitable for further comparative analysis without any single-pixel inclusions. The same vegetation classes were selected from the actual vegetation map with the addition of mixed classes; for example, the Coastal Sage Scrub class was extended by adding Grassland to make Coastal Sage Scrub/Grassland.

The classic book Terrestrial Vegetation of California (Barbour and Major 1977) contains an insert map of the PNV of California (Küchler 1977). Developed at the scale of the state, the map contains 54 plant communities, 4 of which are found on Catalina Island (Küchler 1977). This is the only known map of the PNV of Catalina Island, and so despite the differences in spatial resolution, we compared our composite map with it by selecting 4 vegetation classes that corresponded to the 4 types mapped by Küchler. We then took a random sample of 10,000 points, created contingency tables comparing the 2 maps, and tested significance using a chi-square test implemented in JMP Pro 12 software (SAS Institute, Inc., Cary, NC).

\section{RESULTS}

A model was created for each vegetation class, with performance ranging from fair (AUC $>0.7)$ to good (AUC $>0.8$ ) and excellent (AUC > 0.9) (Table 2, Fig. 2). Less common vegetation classes generally had better model performance, with common vegetation classes having a lower AUC (e.g., Coastal Sage Scrub, Grassland). Environmental variables played differing roles in predicting the distribution of vegetation types (Fig. 3). The relative importance of the environmental variables for modeling each class was assessed by intercomparison of percent contribution, permutation importance, and jackknife importance. Elevation was most important for Coastal Bluff Scrub, Coastal Marsh, Maritime Cactus Scrub, Riparian Herbaceous, and Southern Beach and Dune; solar radiation was most important for Island Chaparral, Island Woodland, and Southern Riparian Woodland; aspect was most 
TABLE 2. Maxent model performance (AUC and SD) and mapping thresholds for each vegetation class.

\begin{tabular}{lccc}
\hline Vegetation class & AUC & SD & Threshold \\
\hline CBS (Coastal Bluff Scrub) & 0.979 & 0.003 & 0.37 \\
CM (Coastal Marsh) & 0.997 & 0.001 & 0.33 \\
CSS (Coastal Sage Scrub) & 0.662 & 0.011 & 0.51 \\
GR (Grassland) & 0.727 & 0.011 & 0.51 \\
IC (Island Chaparral) & 0.722 & 0.010 & 0.37 \\
IW (Island Woodland) & 0.892 & 0.012 & 0.42 \\
MCS (Maritime Cactus Scrub) & 0.990 & 0.005 & 0.40 \\
MFS (Mulefat Scrub) & 0.988 & 0.006 & 0.46 \\
RH (Riparian Herbaceous) & 0.967 & 0.009 & 0.35 \\
SBD (Southern Beach and Dune) & 0.984 & 0.001 & 0.36 \\
SRW (Southern Riparian Woodland) & 0.904 & 0.012 & \\
\hline
\end{tabular}

important for Coastal Sage Scrub; and slope was most important for Mulefat Scrub. Distribution of some vegetation types could be explained almost entirely by topographic attributes, such as Coastal Marsh (extreme low elevation), Southern Beach and Dune (low elevation), and Mulefat Scrub (flat and gentle slopes).

The Maxent results for each class modeling were thresholded and overlaid in ArcGIS to present a map of potential vegetation cover (Fig. 4). We carefully adjusted a threshold value for each class based on the performance of the model. In general, classes with lower AUC values have a higher probability threshold. The rule-based composite map (Supplementary Material 1) showed similar patterns, as expected, because it was based on the same underlying distribution models, but with a substantially reduced distribution of Island Woodland, which was replaced by Island Chaparral.

\section{Comparison of Model with 2005 Vegetation Map}

The modeled potential vegetation corresponds at the broadest levels with the 2005 vegetation map from which it was derived (Fig. 5). The environmental niche models suggest that Island Woodland is more suitable in some areas that are currently Island Chaparral, Coastal Sage Scrub, and Grassland. In addition, some areas that were mapped as Grassland in 2005 have higher suitability values in the model for Coastal Sage Scrub. Overall, the modeled map tracks the topographic layers used as environmental inputs closely and much more distinctly than the actual vegetation. In doing so, it highlights the prevalence of Island Chaparral on north-facing slopes and Coastal Sage Scrub on south-facing slopes.

\section{Comparison of Model with 1977 Potential Natural Vegetation Map}

The patterns of modeled vegetation match the overall patterns proposed by Küchler in his 1977 map. Coastal Sage Scrub dominates on south-facing slopes, Island Chaparral on north-facing slopes, Grassland in the interior, and Island Woodland (which Küchler defined as Southern Oak Woodland) on the southern part of the island (Fig. 5). Each of these relationships is significant in a contingency table analysis (chi-square test: $P<0.05$ ), with the exception of the correspondence between our grassland locations and the Küchler map. Our map predicts more Island Woodland than did Küchler, and more Coastal Sage Scrub in place of Grassland.

\section{Discussion}

The models produced for vegetation classes on Catalina Island are abstractions that do not represent the actual vegetation at any particular moment in history. They do, however, provide quantifiable, replicable representations of the relationship between the environment and vegetation classes that are in many ways consistent with previously observed environmental niches (e.g., Westman 1983). For example, with no a priori requirement to do so, the models confirmed the importance of aspect to the distribution of Island Chaparral and Coastal Sage Scrub. They also indicate that solar radiation is the most important factor determining the distribution of a set of vegetation types that require lower solar radiation and higher moisture to thrive (e.g., Southern Riparian Woodland, Island Woodland, and Island Chaparral). 

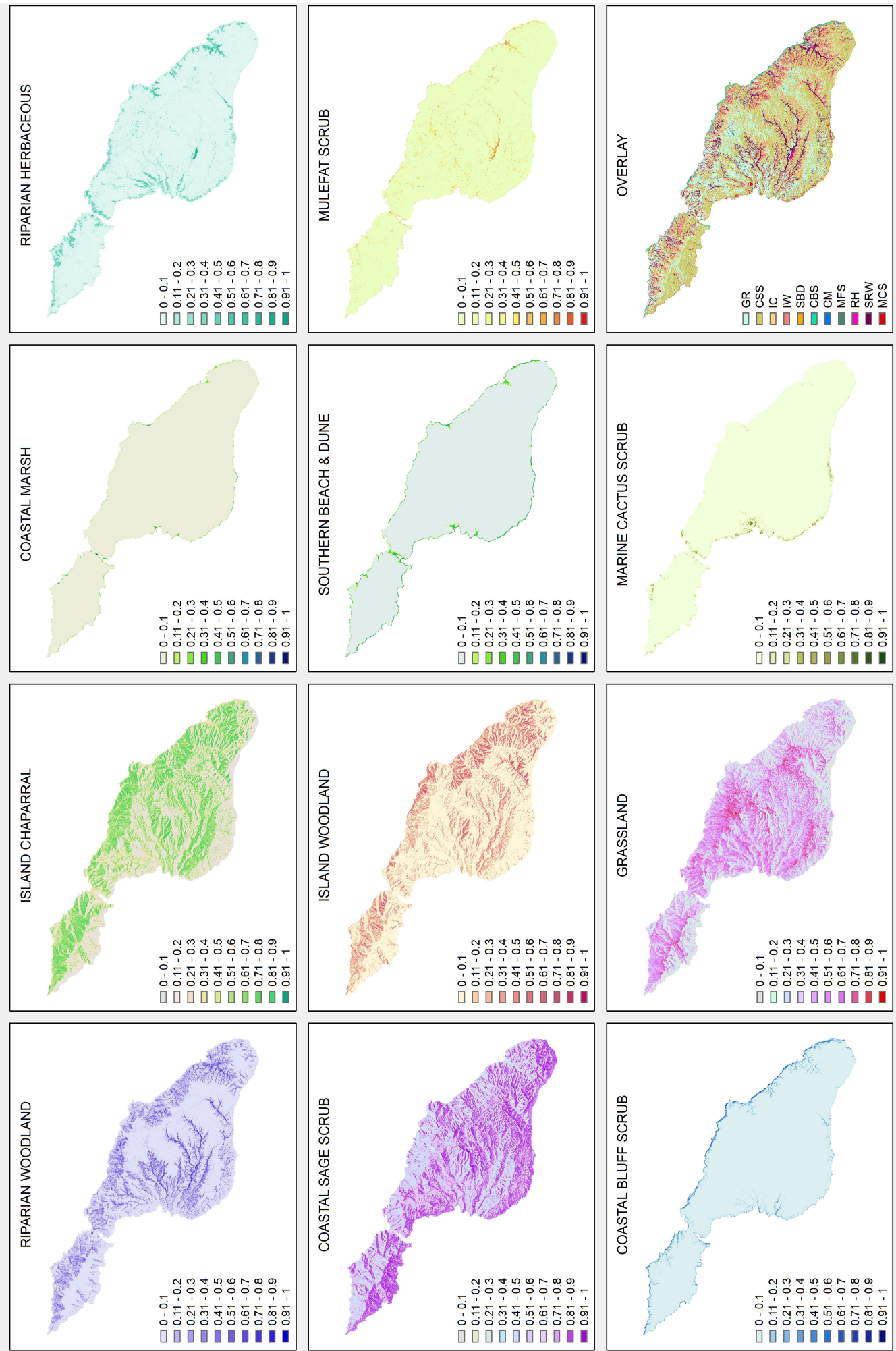

Fig. 2. Habitat suitability models for vegetation types on Santa Catalina Island. See Table 2 for vegetation class codes. 


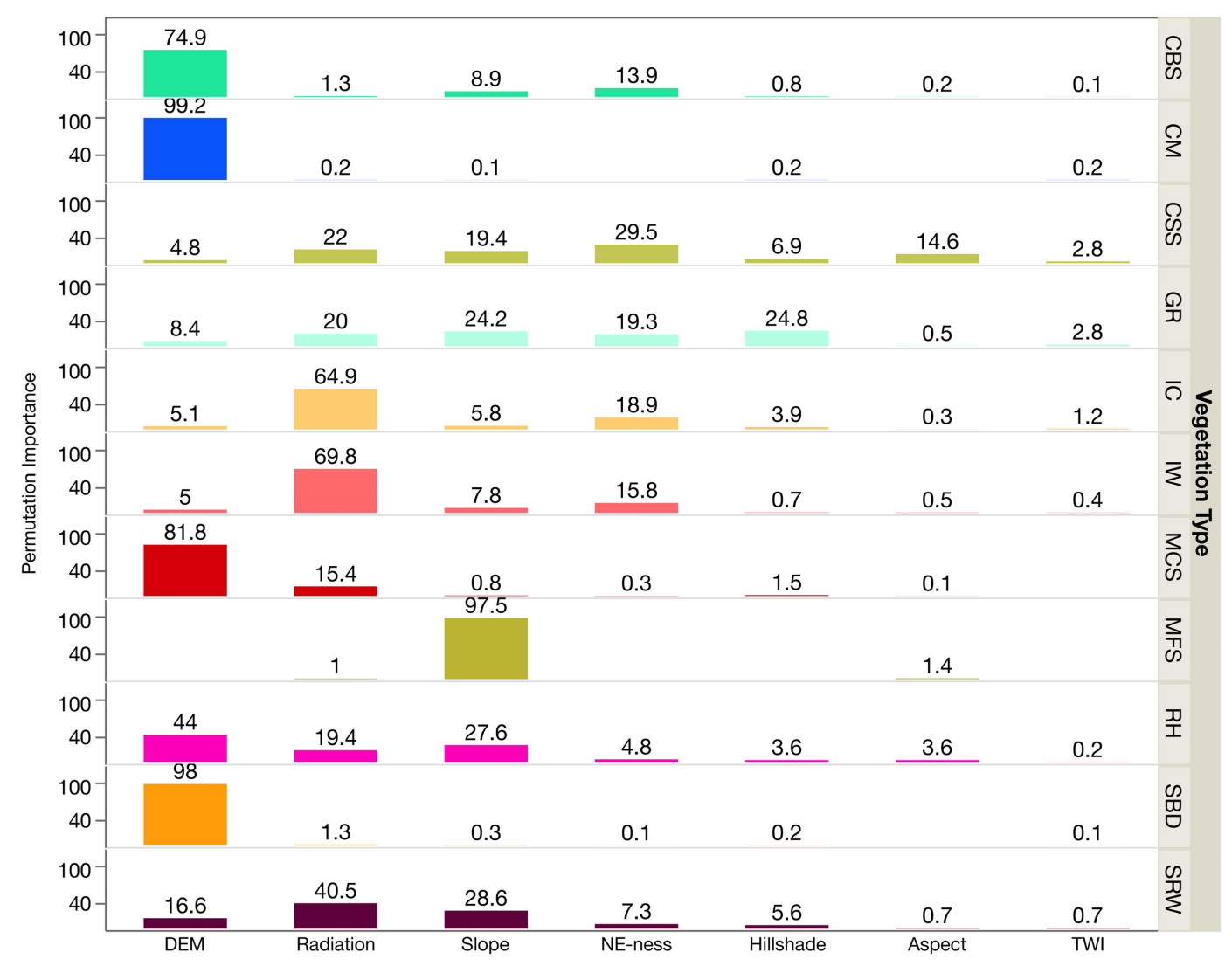

Fig. 3. Permutation importance of each environmental variable to each vegetation type model. See Table 2 for vegetation class codes. $\mathrm{DEM}=$ digital elevation model, $\mathrm{TWI}=$ topographic wetness index.

The models are fraught with all the difficulties of treating vegetation classes as coherent phytosociological units when all evidence indicates that plant species respond individualistically to changes in the environment. The models also represent a problematic spacefor-time substitution by predicting future or past vegetation based on existing conditions that themselves are the result of complex histories not necessarily encapsulated in their topographic positions. Nevertheless, it is an accepted practice to construct PNV maps by extrapolating actual vegetation to areas where native vegetation is absent (Moravec 1998), and as such, the results appear realistic, or at least appear to provide reasonable hypotheses that can be tested.

The question of what is "natural" vegetation for the Channel Islands is not a simple one. The Channel Islands have undergone a series of changes that would have affected vegetation distribution over the past tens of thousands of years. These changes include management of vegetation with fire by indigenous human populations perhaps starting as early as 14-12.5 kya (Hardiman et al. 2016). We are unable to address the many changes in flora and fauna of the late Quaternary but rather have to interpret the modeled vegetation distributions as incorporating disturbance regimes embodied in the 2005 vegetation distribution used as training data. With knowledge of the distribution of human populations and hypotheses about their role in encouraging or discouraging certain keystone plant species (e.g., oaks), distribution modeling could be used to test for that human influence (Tulowiecki and Larsen 2015).

The long-time presence of pigs, sheep, and goats on Catalina Island is likely also to have affected soil depth, character, and erosion (Coblentz 1977, Brumbaugh and Leishman 1982, Minnich 1982, Van Vuren and Coblentz 


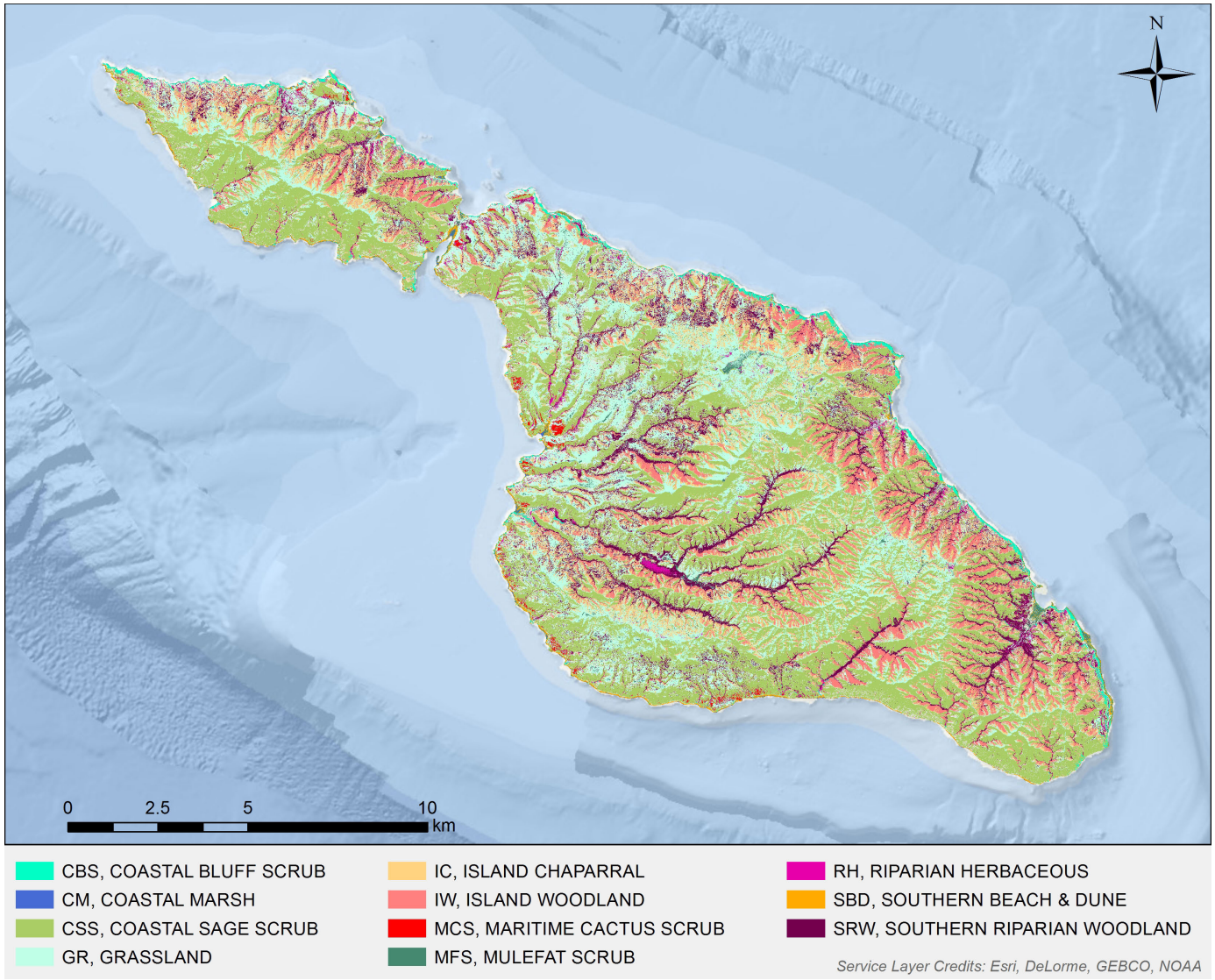

Fig. 4. Composite map of modeled distribution of vegetation on Santa Catalina Island.

1987). We did not include soils in our models because preliminary models showed that soils did not contribute significantly and because the resolution of soils maps is generally lower than the resolution of the environmental data that we did use. Although soils are likely to have changed during the period when pigs, sheep, and goats were present, it is not clear that these changes are as important at the 10 -m scale at which we modeled vegetation distributions. A future effort might investigate the degree to which island topography has been altered in the modern era through erosion and the possible effect that alteration would have at scales relevant to vegetation distribution.

The importance of topography and especially aspect in many models may be attributed to associated environmental variation, such as fog days. Early botanists recognized that fogs were more common on the eastern ridges and at higher elevations - areas that were described as "luxuriously vegetated" (Millspaugh and Nutall 1923)_and modern research confirms the importance of fog for the vegetation of the Channel Islands (Fischer et al. 2009, Fischer et al. 2016). This pattern is evident in our mapping of extensive Island Woodland on the eastern end of the island at higher elevations.

It is generally construed that the PNV represents the state of an environment without disturbance (Jackson 2013). We are not certain this has to be the case, because one can model vegetation that is dependent on disturbance as long as it is defined that the outputs represent vegetation that will be somewhere along a set of successional pathways associated with the overall vegetation type, if underlying ecological processes and conditions (e.g., climate) are stable. The role of natural disturbance on vegetation type distribution on Catalina Island may be smaller than expected. Fire caused by lightning rather than by human ignition is 


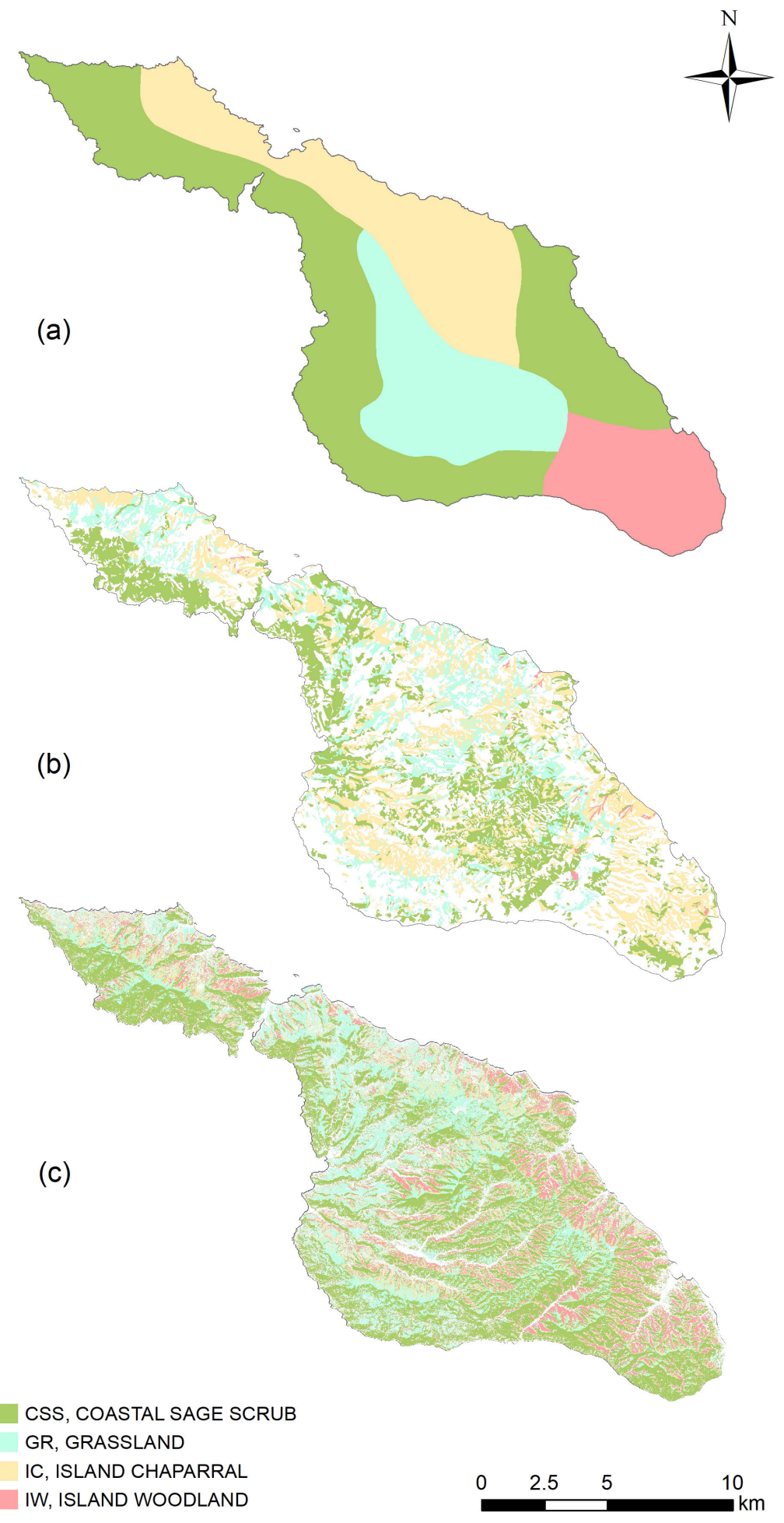

Fig. 5. Comparison of (a) potential natural vegetation (Küchler 1977), (b) 2005 actual vegetation (Knapp 2005), and (c) modeled potential vegetation on Santa Catalina Island, using 4 vegetation units shared in each map: Coastal Sage Scrub, Grassland/California Prairie, Island Chaparral, and Island Woodland. 
extremely uncommon (Minnich 1982, Carroll et al. 1993), likely a result of the maritime conditions (although 3 lightning fires were recorded between 2001 and 2005 in Catalina Island Conservancy records). Fires have occurred in the absence of grazing as exotic grasses increase, but it is not clear that fires naturally (without human influence) would have been common. The remaining disturbances would be relatively limited (e.g., landslides).

The question that then arises is whether our modeled vegetation actually represents the potential distribution of vegetation types on the landscape in the absence of disturbance and whether it is therefore similar to the historic condition before cattle and sheep were introduced in the 1850s. Two lines of evidence speak to these questions.

First, removal of grazing on the current landscape leads to vegetation change. In a series of exclosure experiments undertaken by the Catalina Island Conservancy, postfire Island Chaparral and Island Woodland recovered in exclosures where all exotic grazers were removed but were transformed to grasslands where grazers were present (Fig. 6) (Knapp 2005). Our environmental niche models provide a set of hypotheses about what vegetation types are most likely to reestablish in exclosures or whether exotic herbivore numbers and distributions are otherwise controlled.

Second, a thorough investigation into the historical ecology of Catalina Island could provide evidence of the performance of our models. Historical ecology can refer to both a multi-thousand-year history of a place, spanning the Pleistocene and into the Holocene (Rick et al. 2014), or a description of ecological conditions at some given point prior to a particular intensity of human disturbance (Van Dyke and Wasson 2005, Grossinger et al. 2007). For southern California, historical ecology efforts have focused on defining vegetation and associated species distributions and landscape processes in the late $1800 \mathrm{~s}$, prior to widespread urbanization (Stein et al. 2010, Beller et al. 2011, 2014). This type of investigation could use our modeled distributions as a starting point with which to compare documentary evidence. As a preliminary view, we are optimistic that the evidence would support the patterns we describe.

Minnich (1982) described the replacement of Island Chaparral and Coastal Sage Scrub by grasslands in response to grazing pressure on
Catalina Island, as have others. Our results suggesting a greater distribution of Island Woodland and Island Chaparral are generally consistent with those of other authors who have concluded that these communities have been reduced in extent by grazing (Kindsvater 2010). We do, however, model a considerable area of grassland and lack the detail to specify whether it would indeed be grassland in the absence of the many invasive exotic grass species that characterize the California flora. The grasslands are modeled most along ridgelines where soils are likely to be shallow, and this pattern may indeed hold true in an environment where exotic grasses are aggressively controlled, but this question would certainly be a productive avenue for future research. Future research efforts might, for example, georeference the locations and plant species described by Millspaugh and Nutall (1923) and other early accounts such as Stehman Forney's handwritten journals associated with the 1877 U.S. Coast Survey (Smith 1897, Cockerell 1939). Early photographs, such as those reviewed by Minnich (1982), could also be reviewed and compared with model outputs. Use of such historical sources would help to refine the models and composite maps, especially where they can confirm presence of the vegetation types inhibited by exotic herbivores.

It has been suggested that numerical modeling misses some of the detail found in expert knowledge (Fischer et al. 2013) in the creation of PNV maps. Our results do, however, provide useful hypotheses about past vegetation that would be testable with a detailed historical ecology investigation, and about future vegetation trajectories in the event that grazing pressure is removed. At the least, the quantitative approach used here is replicable and could be modified with a new actual vegetation map or environmental inputs. Furthermore, it demonstrates the further utility of such an approach in creating high-resolution output of PNV that provides spatially explicit hypotheses at the management-relevant scale of meters, which compares favorably with the only other available effort (Küchler 1977).

\section{Supplementary Material}

One online-only supplementary file accompanies this article (scholarsarchive.byu.edu/ wnan/vol78/iss4/12). 


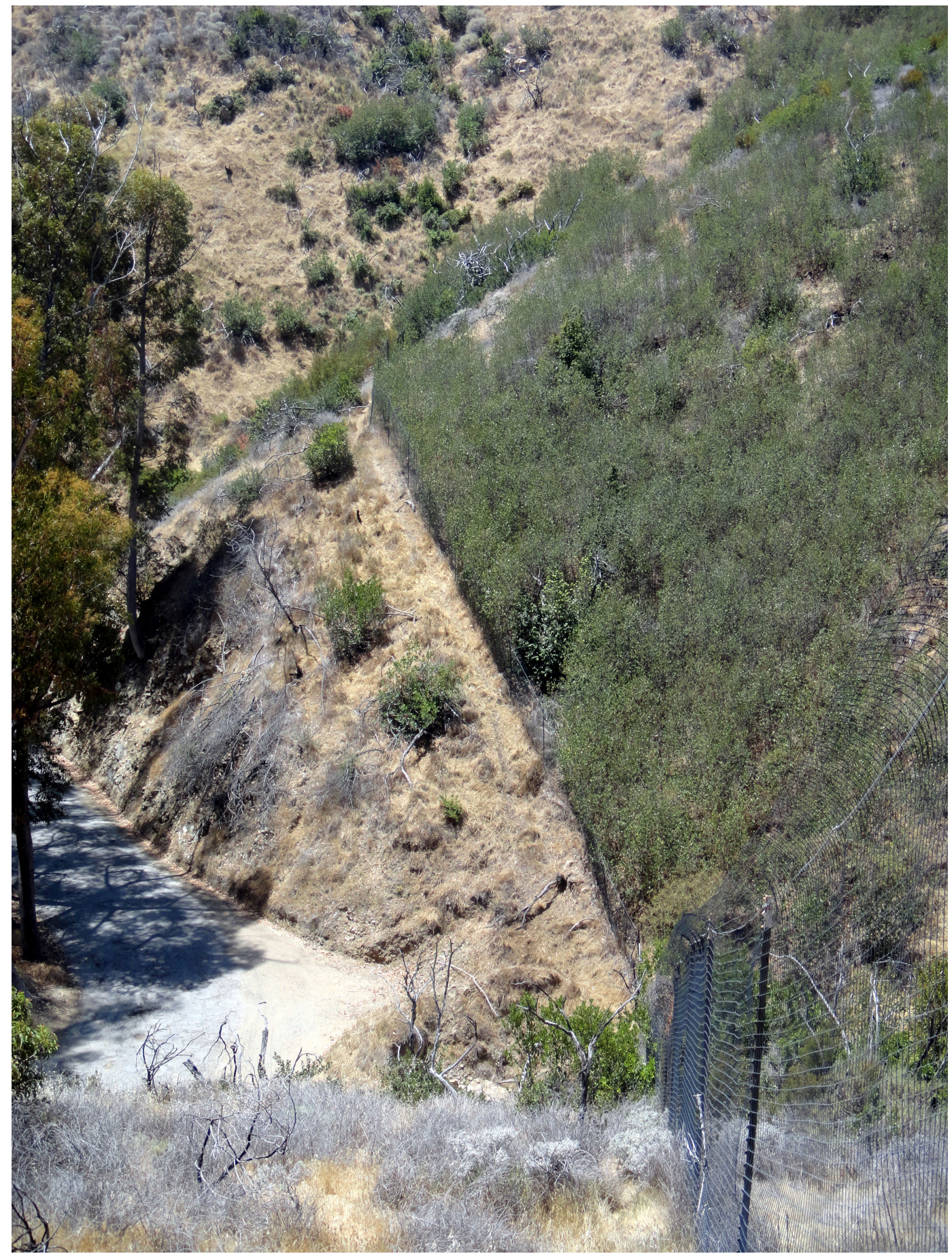

Fig. 6. Example of vegetation recovery in exclosures on Santa Catalina Island. Photo by Amy Catalano. 
Supplementary Material 1. Composite map of modeled vegetation distribution of Santa Catalina Island. Top: Rule-based composite with suitability values normalized to a scale of 0 to 1 and highest value given precedence. Bottom: Models ordered with lower AUC models given precedence and adjusted by hand to avoid exclusion of lower-performing models from the map.

\section{ACKNOWLEDGMENTS}

The University of Southern California Dornsife College of Letters, Arts and Sciences provided seed funding for this research. The Catalina Island Conservancy provided access to key data sets. We thank 2 reviewers for constructive and insightful comments.

\section{Literature Cited}

Akhter, S., M.A. McDonald, P. van Breugel, S. Sohel, E.D. KJaER, AND R. MariotT. 2017. Habitat distribution modelling to identify areas of high conservation value under climate change for Mangifera sylvatica Roxb. of Bangladesh. Land Use Policy 60:223-232.

Babar, S., G. Amarnath, C.S. Reddy, A. Jentsch, and S. SUDHAKAR. 2012. Species distribution models: ecological explanation and prediction of an endemic and endangered plant species (Pterocarpus santalinus L.f.). Current Science 102:1157-1165.

Barbour, M.G., AND J. Major. 1977. Terrestrial vegetation of California. Wiley-Interscience, New York, NY.

Beller, E., S. Baumgarten, R. Grossinger, T. LongCore, E. Stein, S. Dark, and S. Dusterhoff. 2014. Northern San Diego County lagoons historical ecology investigation: regional patterns, local diversity, and landscape trajectories. San Francisco Estuary Institute, Richmond, CA.

Beller, E.E., R.M. Grossinger, M.N. Salomon, S.J. Dark, E.D. Stein, B.K. Orr, P.W. Downs, T.R. LongCore, G.C. Coffman, A.A. Whipple, et aL. 2011. Historical ecology of the Lower Santa Clara River, Ventura River, and Oxnard Plain: an analysis of terrestrial, riverine, and coastal habitats. San Francisco Estuary Institute, Oakland, CA.

Bertram, J., and R.C. Dewar. 2015. Combining mechanism and drift in community ecology: a novel statistical mechanics approach. Theoretical Ecology 8: 419-435.

Bose, R., F. Munoz, B.R. Ramesh, and R. Pelissier. 2016. Past potential habitats shed light on the biogeography of endemic tree species of the Western Ghats biodiversity hotspot, South India. Journal of Biogeography 43:899-910.

Bromberg, J.E., S. Kumar, C.S. Brown, and T.J. StohlGREN. 2011. Distributional changes and range predictions of downy brome (Bromus tectorum) in Rocky Mountain National Park. Invasive Plant Science and Management 4:173-182.

Brumbaugh, R., and N. Leishman. 1982. Vegetation change on Santa Cruz Island, California: the effect of feral animals [sheep grazing]. USDA Forest Service General Technical Report PSW-58, Pacific Southwest Forest and Range Experiment Station (USA).
BRYN, A. 2008. Recent forest limit changes in south-east Norway: effects of climate change or regrowth after abandoned utilisation? Norsk Geografisk TidsskriftNorwegian Journal of Geography 62:251-270.

Brzeziecki, B., F. Kienast, and O. Wildi. 1993. A simulated map of the potential natural forest vegetation of Switzerland. Journal of Vegetation Science 4: 499-508.

Camps, D., D. Villero, J. Ruiz-Olmo, and L. Brotons. 2016. Niche constraints to the northwards expansion of the common genet (Genetta genetta, Linnaeus 1758) in Europe. Mammalian Biology 81:399-409.

Carrión, J.S., AND S. Fernández. 2009. The survival of the 'natural potential vegetation' concept (or the power of tradition). Journal of Biogeography 36 : 2202-2203.

Carroll, M.C., L.L. Laughrin, and A.C. Bromfield. 1993. Fire on the California islands: does it play a role in chaparral and closed cone pine forest habitats? Pages 73-88 in F.G. Hochberg, editor, Third California Islands Symposium: recent advances in research on the California islands.

Choudhury, M.R., P. Deb, H. Singha, B. Chakdar, and M. MedHi. 2016. Predicting the probable distribution and threat of invasive Mimosa diplotricha Suavalle and Mikania micrantha Kunth in a protected tropical grassland. Ecological Engineering 97:23-31.

Coblentz, B.E. 1977. Some range relationships of feral goats on Santa Catalina Island, California. Journal of Range Management 30:415-419.

Cockerell, T.D.A. 1939. Natural history of Santa Catalina Island. Scientific Monthly 48:308-318.

Collette, L.K.D., AND J. Pither. 2015. Modeling the potential North American distribution of Russian olive, an invader of riparian ecosystems. Plant Ecology 216:1371-1383.

Del Río, S., ANd A. Penas. 2006. Potential areas of evergreen forests in Castile and Leon (Spain) according to future climate change. Phytocoenologia 36 : $45-66$

Donlan, C.J., D.A. Croll, and B.R. Tershy. 2003. Islands, exotic herbivores, and invasive plants: their roles in coastal California restoration. Restoration Ecology 11:524-530.

Duursma, D.E., R.V. Gallagher, E. Roger, L. Hughes, P.O. Downey, and M.R. Leishman. 2013. Nextgeneration invaders? Hotspots for naturalised sleeper weeds in Australia under future climates. PLOS ONE 8:e84222

Elith, J., S.J. Phillips, T. Hastie, M. Dudík, Y.E. Chee, AND C.J. Yates. 2011. A statistical explanation of MaxEnt for ecologists. Diversity and Distributions $17: 43-57$.

FABER, A. 1937. Erläuterungen zum pflanzensoziologischen Kartenblatt des mittleren Neckar- und des Ammertalgebietes. Forstdirektion und Württemberg Naturaliensammlung, Stuttgart.

Fischer, D.T., C.J. Still, C.M. Ebert, S.A. Baguskas, and A. Park Williams. 2016. Fog drip maintains dry season ecological function in a California coastal pine forest. Ecosphere 7(6):e01364.

Fischer, D.T., C.J. STILl, AND A.P. Williams. 2009. Significance of summer fog and overcast for drought stress and ecological functioning of coastal California endemic plant species. Journal of Biogeography 36:783-799. 
Fischer, H.S., S. Winter, E. Lohberger, H. Jehl, AND A. Fischer. 2013. Improving transboundary maps of potential natural vegetation using statistical modeling based on environmental predictors. Folia Geobotanica 48:115-135.

FrankLin, J., AND D.A. KNapp. 2010. Habitat relationships and potential restoration sties for Quercus pacifica and Q. tomentella on Catalina Island. Pages 69-94 in D.A. Knapp, editor, Oak ecosystem restoration on Santa Catalina Island, California: proceedings of an on-island workshop, February 2-4, 2007. Catalina Island Conservancy, Avalon, CA.

Gallizia Vuerich, L., L. Poldini, and E. Feoli. 2001. Model for the potential natural vegetation mapping of Friuli Venezia-Giulia (NE Italy) and its application for a biogeographic classification of the region. Plant Biosystems 135:319-335.

Gaucherel, C., R. Vezy, F. Gontrand, D. Bouchet, and B.R. Ramesh. 2016. Spatial analysis of endemism to redefine conservation areas in Western Ghats (India). Journal for Nature Conservation 34:33-41.

Grossinger, R., C. Striplen, R. Askevold, E. BrewSTER, AND E. BELLER. 2007. Historical landscape ecology of an urbanized California valley: wetlands and woodlands in the Santa Clara Valley. Landscape Ecology 22:S103-S120.

Hardiman, M., A.C. Scott, N. Pinter, R.S. Anderson, A. Ejarque, A. Carter-Champion, and R.A. Staff. 2016. Fire history on the California Channel Islands spanning human arrival in the Americas. Philosophical Transactions of the Royal Society B-Biological Sciences 371:20150167.

HÄrDTLE, W. 1995. On the theoretical concept of the potential natural vegetation and proposal for an up-to-date modification. Folia Geobotanica et Phytotaxonomica 30:263-276.

Hemsing, L.Ø., AND A. BRYn. 2012. Three methods for modelling potential natural vegetation $(\mathrm{PNV})$ compared: a methodological case study from south-central Norway. Norsk Geografisk Tidsskrift-Norwegian Journal of Geography 66:11-29.

JACKSON, S.T. 2013. Natural, potential and actual vegetation in North America. Journal of Vegetation Science 24:772-776.

Keitt, B.S., C. Wilcox, B.R. Tershy, D.A. Croll, and C.J. Donlan. 2002. The effect of feral cats on the population viability of Black-vented Shearwaters (Puffinus opisthomelas) on Natividad Island, Mexico. Animal Conservation 5:217-223.

Kindsvater, L. 2010. Plant communiites associated with the rare, paleoendemic oak, Quercus tomentella on Santa Cruz and Santa Rosa Islands, California. Pages 53-68 in D.A. Knapp, editor, Oak ecosystem restoration on Santa Catalina Island, California: proceedings of an on-island workshop, February 2-4, 2007. Catalina Island Conservancy, Avalon, CA.

KNAPP, D.A. 2005. Vegetation community mapping on Santa Catalina Island using orthorectification and GIS. Pages 193-203 in D.K. Garcelon and C.A. Schwemm, editors, Proceedings of the Sixth California Islands Symposium. National Park Service Technical Publication CHIS-05-01. Institute for Wildlife Studies, Arcata, CA.

KNAPP, D.A. 2010a. Changes in oak distribution and density by decade on Santa Catalina Island, 1943 to 2005. Pages 47-52 in D.A. Knapp, editor, Oak ecosystem restoration on Santa Catalina Island, California: proceedings of an on-island workshop, February 2-4, 2007. Catalina Island Conservancy, Avalon, CA.

KNAPP, D.A. 2010b. Ecosystem restoration on Santa Catalina Island: a synthesis of resources and threats. Pages 135-216 in D.A. Knapp, editor, Oak ecosystem restoration on Santa Catalina Island, California: proceedings of an on-island workshop, February 2-4, 2007. Catalina Island Conservancy, Avalon, CA.

Krujer, H., N. Raes, and M. Stech. 2010. Modelling the distribution of the moss species Hypopterygium tamarisci (Hypopterygiaceae, Bryophyta) in Central and South America. Nova Hedwigia 91:399-420.

KüChleR, A.W. 1977. Natural vegetation of California. Map in M.G. Barbour and J. Major, editors, Terrestrial vegetation of California. Wiley-Interscience, New York, NY.

KüChler, A.W., AND I.S. Zonneveld, EDITORS. 1988. Vegetation mapping. Kluwer Academic Publishers, Dordrecht.

Lapola, D.M., M.D. Oyama, C.A. Nobre, and G. Sampaio. 2008. A new world natural vegetation map for global change studies. Annals of the Brazilian Academy of Sciences 80:397-408.

Liu, H., L. Wang, J. Yang, N. Nakagoshi, C. Liang, W. WANG, AND Y. Lv. 2009. Predictive modeling of the potential natural vegetation pattern in northeast China. Ecological Research 24:1313-1321.

[LAR-IAC] Los Angeles Region Imagery ACQuisition Consortium. 2006. LARIAC1 Archive. Los Angeles County GIS Data Portal. https://egis3.lacounty.gov/ dataportal/lariacl-archive

Marino, J., M. Bennett, D. Cossios, A. Iriarte, M. Lucherini, P. Pliscoff, C. Sillero-Zubiri, L. VilLALBA, AND S. WALKER. 2011. Bioclimatic constraints to Andean cat distribution: a modelling application for rare species. Diversity and Distributions 17:311-322.

McDowell, W.G., A.J. Benson, And J.E. Byers. 2014. Climate controls the distribution of a widespread invasive species: implications for future range expansion. Freshwater Biology 59:847-857.

Millspaugh, C.F., and L.W. Nutall. 1923. Flora of Santa Catalina Island (California). Field Museum of Natural History, Botanical Series 5:1-413.

Minnich, R.A. 1980. Vegetation of Santa Cruz and Santa Catalina Islands. Pages 123-138 in D.M. Power, editor, The California islands: proceedings of a multidisciplinary symposium. Santa Barbara Museum of Natural History Santa Barbara, CA.

Minnich, R.A. 1982. Grazing, fire, and the management of vegetation on Santa Catalina Island, California. Pages 444-449 in Dynamics and management of Mediterranean-type ecosystems. Pacific Southwest Forest and Range Experiment Station, Berkeley, CA.

Moravec, J. 1969. Succession of plant communities and soil development. Folia Geobotanica et Phytotaxonomica 4:133-164.

MoRAvec, J. 1998. Reconstructed natural versus potential natural vegetation in vegetation mapping: a discussion of concepts. Applied Vegetation Science 1:173-176.

Nazeri, M., N. Madani, L. Kumar, A.S. Mahiny, and B.H. KIABI. 2015. A geo-statistical approach to model Asiatic cheetah, onager, gazelle and wild sheep shared niche and distribution in Turan Biosphere Reserve-Iran. Ecological Informatics 29:25-32.

Newbold, T., T. Reader, S. Zalat, A. El-Gabbas, and F. GILBERT. 2009. Effect of characteristics of butterfly species on the accuracy of distribution models in 
an arid environment. Biodiversity and Conservation 18:3629-3641.

Nogales, M., A. Martín, B.R. Tershy, C.J. Donlan, D. Veitch, N. Puerta, B. Wood, and J. Alonso. 2004. A review of feral cat eradication on islands. Conservation Biology 18:310-319.

Palmer, M.W. 1993. Putting things in even better order: the advantages of canonical correspondence analysis. Ecology 74:2215-2230.

Papeş, M., A.T. Peterson, ANd G.V.N. Powell. 2012. Vegetation dynamics and avian seasonal migration: clues from remotely sensed vegetation indices and ecological niche modelling. Journal of Biogeography 39: $652-664$

Paudel, S., G.W.T. Wilson, B. MacDonald, T. LongCORE, AND S.R. Loss. 2016. Predicting spatial extent of invasive earthworms on an oceanic island. Diversity and Distributions 22:1013-1023.

Phillips, S.J., R.P. Anderson, and R.E. Schapire. 2006. Maximum entropy modeling of species geographic distributions. Ecological Modelling 190:231-259.

Phillips, S.J., AND M. DudíK. 2008. Modeling of species distributions with Maxent: new extensions and a comprehensive evaluation. Ecography 31:161-175.

RaEs, N., AND H. Ter SteEge. 2007. A null model for significance testing of presence-only species distribution models. Ecography 30:727-736.

Ramirez, A.R., R.B. Pratt, A.L. Jacobsen, and S.D. Davis. 2012. Exotic deer diminish post-fire resilience of native shrub communities on Santa Catalina Island, southern California. Plant Ecology 213:1037-1047.

Rick, T.C., T.S. Sillett, C.K. Ghalambor, C.A. Hofman, K. Ralls, R.S. Anderson, C.L. Boser, T.J. Braje, D.R. Cayan, R.T. Chesser, ET AL. 2014. Ecological change on California's Channel Islands from the Pleistocene to the Anthropocene. BioScience 64: 680-692.

Roberts, D.W. 1986. Ordination on the basis of fuzzy set theory. Vegetatio 66:123-131.

Rodríguez-SÁnchez, F., AND J. ARroyo. 2008. Reconstructing the demise of Tethyan plants: climate-driven range dynamics of Laurus since the Pliocene. Global Ecology and Biogeography 17:685-695.

Rowland, S.M. 1984. Geology of Santa Catalina Island. California Geology 37:239-251.

Schoenherr, A.A., C.R. Feldmeth, and M.J. Emerson. 1999. Natural history of the islands of California. University of California Press, Berkeley, CA.

Simpson, M., AND B. Prots. 2013. Predicting the distribution of invasive plants in the Ukrainian Carpathians under climatic change and intensification of anthropogenic disturbances: implications for biodiversity conservation. Environmental Conservation 40:167-181.

Smith, W.S.T. 1897. The geology of Santa Catalina Island. California Academy of Sciences.

Soto-Berelov, M., P.L. Fall, S.E. Falconer, and E. RIDDER. 2015. Modeling vegetation dynamics in the Southern Levant through the Bronze Age. Journal of Archaeological Science 53:94-109.

Stein, E.D., S. Dark, T. Longcore, R. Grossinger, N. HALL, AND M. BELAND. 2010. Historical ecology as a tool for assessing landscape change and informing wetland restoration priorities. Wetlands 30:589-601.

Stratton, L. 2009. Restoration strategies for overcoming limitations to scrub oak regeneration on Catalina
Island. Pages 185-200 in Proceedings of the 7th California Islands Symposium. Institute for Wildlife Studies, Arcata, CA.

Szabó, P., P. Kuneš, H. Svobodová-Svitavská, M.G. Švarcová, L. KŘížová, S. Suchánková, J. Müllerová, AND R. HÉDL. 2017. Using historical ecology to reassess the conservation status of coniferous forests in Central Europe. Conservation Biology 31:150-160.

TaYlor, P.J., A. Nengovhela, J. Linden, and R.M. BaXTER. 2016. Past, present, and future distribution of Afromontane rodents (Muridae: Otomys) reflect climate-change predicted biome changes. Mammalia $80: 359-375$.

Thorne, R.F. 1967. A flora of Santa Catalina Island, California. Aliso 6:1-77.

TICHÝ, L. 1999. Predictive modeling of the potential natural vegetation pattern in the Podyjí National Park, Czech Republic. Folia Geobotanica 34:243-252.

Tingley, R., M. Vallinoto, F. Sequeira, and M.R. KearNEY. 2014. Realized niche shift during a global biological invasion. Proceedings of the National Academy of Sciences of the United States of America 111:10233-10238.

Tulowiecki, S.J., AND C.P. LaRSEN. 2015. Native American impact on past forest composition inferred from species distribution models, Chautauqua County, New York. Ecological Monographs 85:557-581.

Tüxen, R. 1956. Die heutige potentielle natürliche Vegetation als Gegenstand der Vegetationskartierung. Angewandte Pflanzensoziologie 13:4-42.

Van DyKe, E., AND K. Wasson. 2005. Historical ecology of a central California estuary: 150 years of habitat change. Estuaries and Coasts 28:173-189.

VAN Vuren, D., AND B.E. CoblentZ. 1987. Some ecological effects of feral sheep on Santa Cruz Island, California, USA. Biological Conservation 41:253-268.

Velásquez-Tibatá, J., P. Salaman, and C.H. Graham. 2013. Effects of climate change on species distribution, community structure, and conservation of birds in protected areas in Colombia. Regional Environmental Change 13:235-248.

Westman, W.E. 1983. Island biogeography: studies on the xeric shrublands of the inner Channel Islands, California. Journal of Biogeography 10:97-118.

Westoff, V., AND E. VAN DER MaAREL. 1978. The BraunBlanquet approach. Pages 287-399 in R.H. Whittaker, editor, Classification of plant communities. Junk, The Hague.

Wollan, A.K., V. Bakkestuen, H. Kauserud, G. Gulden, AND R. Halvorsen. 2008. Modelling and predicting fungal distribution patterns using herbarium data. Journal of Biogeography 35:2298-2310.

Zerbe, S. 1998. Potential natural vegetation: validity and applicability in landscape planning and nature conservation. Applied Vegetation Science 1:165-172.

Zhang, Z.D., R.G. Zang, and M. Convertino. 2013. Predicting the distribution of potential natural vegetation based on species functional groups in fragmented and species-rich forests. Plant Ecology and Evolution 146:261-271.

Received 28 February 2017 Revised 27 February 2018 Accepted 14 March 2018

Published online 17 December 2018 